\title{
Stability of the Railway Subgrade under Condition of Its Elements Damage and Severe Environment
}

\author{
Vitalii Kovalchuk ${ }^{1, *}$, Mykola Sysyn $^{2}$, Olga Nabochenko ${ }^{1}$, Andrii Pentsak ${ }^{3}$, Oleh Voznyak ${ }^{1}$ and Stepan Kinter $^{1}$ \\ ${ }^{1}$ Dnipro National University of Railway Transport named after Academician V. Lazaryan, Lviv Branch, I. Blazhkevych str., 12-a, \\ Lviv, 79052, Ukraine \\ ${ }^{2}$ Institute of Railway Systems and Public Transport, Technical University of Dresden, Dresden, Germany \\ ${ }^{3}$ Lviv Polytechnic National University, S. Bandery str., 12, Lviv, 79013, Ukraine
}

\begin{abstract}
Investigation of damages of the subgrade slope in combination with its overwetting and rolling stock loading, which significantly affects safety traffic of the railway transport, has been carried out. The complex method of slope stability estimation of the subgrade is developed, which includes calculation of loads and vibration action of rolling stock on the main site of the subgrade, as well as the dynamic model of vibrations propagation in the body of the subgrade embankment and the model of plastic deformations accumulation. Dynamic and nonlinear plastic models are based on a finite-element model of the cross section of the subgrade. The plastic model takes into account the characteristics of soil strength of the subgrade, depending on the area of the vibration load impact. The developed method allows to carry out the estimation of external and internal factors impact on occurrence of subgrade destruction, which is of practical value for safety state estimation of the railway transport.
\end{abstract}

\section{INTRODUCTION}

Railway subgrade embankment is one of the most critical parts of railway infrastructure. The failures in railway embankments require continual maintenance and repair works that leads to enormous maintenance costs, decrease of reliability and availability of railway transportation [1,2]. Moreover, embankments failures, together with other unfavourable factors can cause the reduction of slope stability and risk of train derailment $[3,4,5]$. The stability of the railway subgrade is simultaneously influenced by a number of factors: maintenance works implementation the state of culverts, atmospheric precipitation, loading of rolling stock. In addition to these factors, the factor of subgrade state is also important due to the heterogeneous geological structure and weak soils of the embankment and the foundation, that is, the presence of the defect subgrade. In assessing the stability of the embankment, it is necessary to determine the contribution of each of the factors to the occurrence of subgrade landslide. A study of moisture values of subgrade construction materials depending on climatic factors is presented in [6].

The impact of the rolling stock on the stability of the subgrade is both static and dynamic loading of sleepers on the ballast prism and the subgrade. On the one hand, static and dynamic loading leads to the increase of landslide stresses, which, when exceeding the permissible value, causes plastic deformation, and on the other hand, dynamic vibrational loading results in the loss of friction and adhesion between soil particles. The loading of the rolling stock, in its turn, depends on many factors of rolling stock and the track, namely, the speed of movement and others. The influence of rolling stock dynamic loading on railway subgrade and ballast materials is presented in [7-10]

The critical issue is the quantitative assessment of interconnections of the effects of maintenance, state and characteristics of both the subgrade and the superstructure, taking into account rolling stock loading and the state of its running parts [11-12]. The basis for solving this problem is mathematical modeling of the processes of elastic and irreversible deformations of the subgrade in mutual connection with rolling stock loads on the upper structure of the track. Such formulation of the problem allows to take into account not only the possibility of rolling stock derailment as a result of subgrade subsidence, but also to depict the process of state transition of a railway from operable and working to marginal and non-working. At present, the model of elastic and plastic deformations of the subgrade is most widely used on the basis of the finite element method and the criteria of plasticity of Mohr-Coulomb or Drucker-Prager. Proceeding from practical possibility of obtaining information on soils characteristics and the characteristics of railways subgrade, as well as the necessary of calculations accuracy, the problem of elasticity and plasticity in flat formulation is optimal. In addition to model developing, it is important to take into account the impact of vibration loading of the rolling stock on the mechanical characteristics of soils in the transverse section of the subgrade body. 
Along with considered advantages of the models of elastic and plastic deformations of the substructure of the track, there are also a number of shortcomings, that is mathematical complexity of models, the need for the development of specific software for practical application, the need for output for the calculation of the parameters of soil characteristics, which are determined experimentally, although they are not always available. In this regard, it is advisable to consider simpler methods for calculating the borderline state of the subgrade, which, under condition of some uncertainty of background data on soils, can give an answer about potential destruction of the subgrade. Due to the simplicity of these techniques and their possible implementation without the use of specialized software, they can be more widely used in assessing the safety of the railway transport.

The present paper deals with the study of slope of railway embankments under condition of its damage and severe environment and operational loading. For assessing the subgrade stability, the calculation of vertical loading of a sleeper on the ballast that arises during movement of corresponding components of a train with actual speeds in accordance with the existing standard methodology and instructions is carried on. To determine the effect of dynamical vibrational loads on the mechanical properties of soils, it is necessary to calculate the distribution of dynamical displacements of soil points of the embankment, which is performed using the principle of dynamical theory of elasticity. This takes into account vibrational dynamical loading caused by fluctuations of unsprung masses of a train as a result of movement along separate track irregularity, continuous wheel irregularity and the presence of wheel sliders. The solution of the dynamical problem is an iterative solution of a static task with regard inertial forces. As a result of calculation of the impact of dynamical vibrational loading on mechanical properties of soils, the field of distribution of specific adhesion and the angle of internal friction in the cross section of the embankment were obtained, which were taken into account in calculations of plastic deformations later.

\section{Calculation of vertical force action of a sleeper on the ballast during trains traffic}

Rolling stock, moving by the railway, transfers dynamic loading on the rails, sleepers, ballast and the subgrade. The acting forces of rolling stock depend on a number of factors, the most important of which are the weight of rolling stock, speed, mechanical characteristics of the suspension and the running gear of rolling stock, geometric state of the railway track and its mechanical characteristics. The vertical forces of rolling stock acting on the track and their distribution in the elements of the track are determined according to the "Rules of calculating railway track strength and stability" being valid for the railways of Ukraine [13]. The distribution of vertical forces from rolling stock to the rails is determined by the methodology of a number of authors [5-8].
Calculation of vertical force of a sleeper acting on the ballast consists of two parts:

1) calculation of vertical dynamic loads of rolling stock acting on rails;

2) calculation of vertical forces distribution acting on the elements of the track.

Dynamic loads from a single wheel acting on a rail and from a group of wheels are calculated in accordance with clauses 2.4.1-2.5.4 of the Rules TsP-0117 [13].

\section{Calculation of impact-vibration loads of rolling stock}

This calculation is carried out for determining the distribution of oscillation amplitude $\mathrm{A}$ in the subgrade and further evaluating shock-vibration loads impact on strength parameters $\mathrm{C}_{d y n}$ and $\varphi_{d y n}$ for each type of soil of the subgrade.

For this purpose, a developed model of dynamic oscillations of the subgrade in the transverse plane is used. The starting data for calculation are:

1) mechanical properties of soils obtained from the results of geological survey and reference literature: deformation module $U$, specific gravity $m$ and Poisson coefficient;

2) external vibration loads on the ballast layer at the given speed of rolling stock are taken as a sum of impulses of harmonics of the function:

$$
F(t)=F_{p}(t)+F_{t i}(t)+F_{s w i}(t)+F_{c w i}(t)
$$

The resulting dynamic loads on the ballast layer is:

$$
F(t)=p_{s}^{d y n}\left(\begin{array}{l}
\frac{S_{p}^{2}}{\bar{S}^{2}} \sin \left(\frac{2 \pi}{T_{p}} t\right)+\frac{S_{t i}^{2}}{\bar{S}^{2}} \sin \left(\frac{2 \pi}{T_{t i}} t\right)+ \\
+0,05 \frac{S_{s w i}^{2}}{\bar{S}^{2}} \sin \left(\frac{2 \pi}{T_{s w i}} t\right)+0,95 \frac{S_{c w i}^{2}}{\bar{S}^{2}} \sin \left(\frac{2 \pi}{T_{c w i}} t\right)
\end{array}\right)
$$

where $p_{s}^{d y n}$ is the amplitude of the dynamic force of the sleepers on the ballast per 1 running meter of the track, which is calculated in accordance with the Rules [13]; $S_{p}^{2}, \quad S_{t i}^{2}, \quad 0,05 S_{s w i}^{2}, \quad 0,95 S_{c w i}^{2}$ are components of the composition of distribution laws of the mean deviation of dynamic vertical loads; $T_{p}, T_{t i}, T_{s w i}, T_{c w i}$ are periods of impact-vibration loads.

The basis for calculating dynamic loads action of rolling stock on the track is the Rules [13], where the rule of forces superposition is taken into account that includes the calculation of the total effect of all dynamic loads of different periods of oscillation: from 10-50 m with fluctuations of over-sprung mass of a carriage, 3-5 $\mathrm{m}$ from unevenness of the railway up to $15-20 \mathrm{~cm}$ with separate roughness of rolling stock wheels. For the given calculation, only those oscillation frequencies are important that are relevant to experimental studies of soil vibrational dislocation - 11-50 Hz [14]. The component of oscillations of over-sprung structure in formula (1) in the speed range up to $55 \mathrm{~km} / \mathrm{h}$ corresponds to frequencies of $0.5-2 \mathrm{~Hz}$, so it is not taken into account in the calculation. 
Example of components of formula (1) calculation $S_{t i}^{2}, 0,05 S_{s w i}^{2}, 0,95 S_{c w i}^{2}$ and their periods of oscillation $T_{t i}$, $T_{s w i}, T_{c w i}$ at the speed of $55 \mathrm{~km} / \mathrm{h}$ for a four-axial freight car on the bogies TsNII-X3-0 and for electric locomotive VL-80s is given in Table 1.

The calculated values of the components of the dynamic forces and their periods are used to construct the impact vibration load function $F(t)$ (1), which is further used in simulation of oscillations in the subgrade.

The function $F(t)$ is presented by one load impulse and, in order to ensure its smooth detailing, such a step of time is chosen that within the period of oscillation there were at least 10 points of calculation. With a multiple reserve, the time discretization is taken to be $0.001 \mathrm{sec}$.

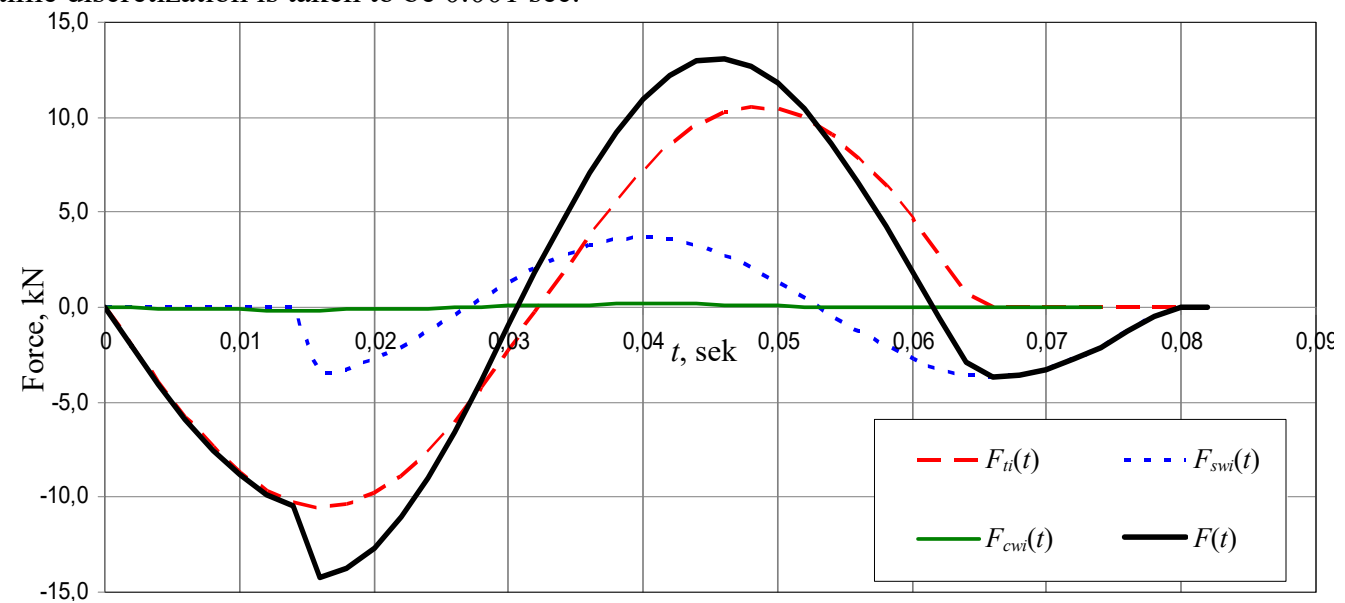

Fig. 1. Chart of time variation of the total dynamic loads on the ballast layer

\section{Calculation of dynamic fluctuations distribution in the subgrade}

For calculation of the impact of shock-vibration loads of rolling stock on the propagation of dynamic oscillations in the subgrade, a finite-element model is used. According to this model, the transverse section of the subgrade (Fig. 2 ) is divided into separate elements, whose properties correspond to one or another type of soil in accordance with the papers of geological research. The division into finite elements is carried out with the aim of detailed description of separate zones of the cross-section with different soil properties. To increase calculating accuracy the slope zone from the side of possible soil sliding, is

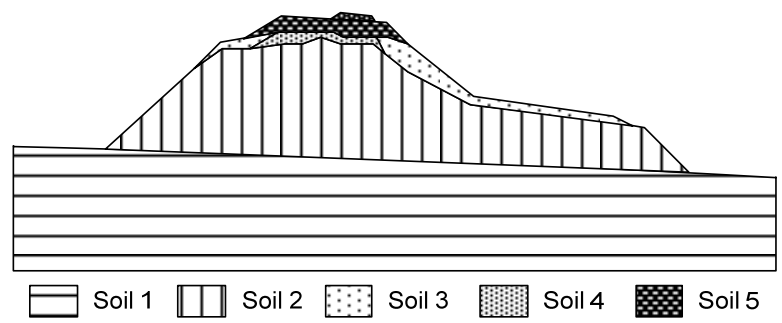

Fig. 2. The scheme of soil distribution in the cross section of the embankment

In order to provide an acceptable calculation time and, taking into account the available computer divided into smaller finite elements.
Table 1. Components of dynamic loads composition and their periods of oscillation

\begin{tabular}{|c|c|c|c|c|c|c|c|}
\hline \multirow{2}{*}{$\begin{array}{c}\text { Velocity of } \\
\text { movement, } \\
\mathrm{km} / \mathrm{h}\end{array}$} & \multicolumn{4}{|c|}{$\begin{array}{l}\text { Components of loads } \\
\text { composition, } \mathrm{kN}\end{array}$} & \multicolumn{3}{|c|}{$\begin{array}{l}\text { Oscillation } \\
\text { periods, sec }\end{array}$} \\
\hline & $S_{t i}^{2}$ & $0,05 S_{s w i}^{2}$ & $0,95 S_{c w i}^{2}$ & $\bar{S}^{2}$ & $T_{t i}$ & $T_{s w i}$ & $T_{c w i}$ \\
\hline \multicolumn{8}{|c|}{ for a four-axial freight car on the bogies TsNII-X3-0 } \\
\hline 55 & 19,47 & 6,77 & 0,29 & 34,3 & & 0,05 & 0,054 \\
\hline \multicolumn{8}{|c|}{ for electric locomotive VL-80 s } \\
\hline 55 & 47,01 & 3,33 & 0,30 & 52,5 & 0,0 & 0,08 & 0,071 \\
\hline
\end{tabular}

The graph (Fig. 1) shows the change in time of total dynamic loads on the ballast layer at rolling stock speed of $55 \mathrm{~km} / \mathrm{h}$. resources, the size of finite elements in the depth of the embankment is enlarged. The scheme of finite elements distribution in the cross section of the embankment and its constituent soils are shown in Fig. 3. The total number of quadrangular 8 -node elements is 687 , the total number of nodes of the elements is 2196. Estimated external dynamic loading from the sleeper is taken as distributed into nodes $12,13,18,19,24,25,30,31,36$, 37, 42, 43, 48, 49 and 54.

The geometrical characteristics of the transverse profile and soil properties of the subgrade should be taken according to geological survey data. For this calculation it is assumed that the body of the embankment consists of the following soils:

Soil 1. Base of the embankment: clay of dense consistency and semi-solid consistency with the following characteristics: soil density - 17,8 kN/m³ deformation module $U-16 \mathrm{MPa}$; yield index (consistency) $I_{L}-0.08$; plasticity number $I_{p}-0.27$. The internal friction angle $\phi-16^{\circ}$ and the specific adhesion $c-36 \mathrm{kPa}$ are taken in accordance with $[14,16]$ regarding yield index and plasticity number.

Soil 2. Body of the embankment: loam with clay layers, with consistency from semisolid to mild plasticity with the following characteristics: soil density $m-17,5 \mathrm{kN} / \mathrm{m}^{3}$; number of plasticity $I_{p}-0.14$; yield index (consistency) $I_{L}$ -0.28 . The internal friction angle $\phi$ is $22^{\circ}$ and the specific adhesion $c-25 \mathrm{kPa}$ taken with regard $[15,16]$ according 
to yield index and plasticity number. Deformation module is adopted according to [9] and is confirmed by a number of sources $[17,18]=13 \mathrm{MPa}$.

Soil 3. Sub-ballast layer: ballast sand with inclusions of crushed stone, non-uniform, of medium density and dense. Data are taken according to reference literature and regulatory documents with regard to DBN V.2.1-102009 and DIN $18196[15,18-20]$ according to classification SE, SU; the angle of internal friction $\phi-$ $32-38^{\circ}$, accepted $\phi-38^{\circ}$ and density $m-19,0 \mathrm{kN} / \mathrm{m}^{3}$ (in the state of natural humidity); deformation module can vary within 48-100 $\mathrm{MPa}$ (from medium compacted state to compacted one), taken - $75 \mathrm{MPa}$; specific adhesion can vary within $2-6 \mathrm{kPa}$, taken $-6 \mathrm{kPa}$.

Soil 4. Ballast plume: quartz sand with gravel inclusion, siliceous gravel and loam, inhomogeneous, from large to medium size, loose. Characteristics are taken in accordance with reference literature and regulations with regard to DBN B.2.1-10-2009 and DIN 18196 [15, 18-20] classified SI, SU, SW; internal friction angle $\phi-28-35^{\circ}$, accepted $\phi-32^{\circ}$ and density $m-18.0 \mathrm{kN} / \mathrm{m}^{3}$ (in the state of natural humidity); deformation module can vary within $18-50 \mathrm{MPa}$ (in the loose state), taken $U-30 \mathrm{MPa}$; specific adhesion - 2-4 $\mathrm{kPa}$, accepted $c-2 \mathrm{kPa}$.

Soil 5. Ballast: crushed stone ballast. Characteristics are taken in accordance with reference literature and regulatory documents, taking into account the fact that crushed stone ballast is in compressed state and without contaminants with regard to $[19,20]$. According to GE classification, the angle of internal friction $\phi=37-65^{\circ}$, accepted $\phi=63^{\circ}$ (for sub-ballast layer $\phi=58^{\circ}$ ) and density $m=20,0 \mathrm{kN} / \mathrm{m}^{3}$; deformation module can vary within 150-300 $\mathrm{MPa}$ (in the loose state), accepted $U$ $=150 \mathrm{MPa}$; the characteristic of specific clutch in crushed stone is absent, but this material has a similar property of another nature, that is spike-tooth adhesion, which is $0.8-0.92 \mathrm{kPa}$ and accepted $c=0.9 \mathrm{kPa}$ (for subballast layer $c=0.5 \mathrm{kPa}$ ).

Possible distribution scheme of soils in the transverse section of the embankment is shown in Fig. 4.

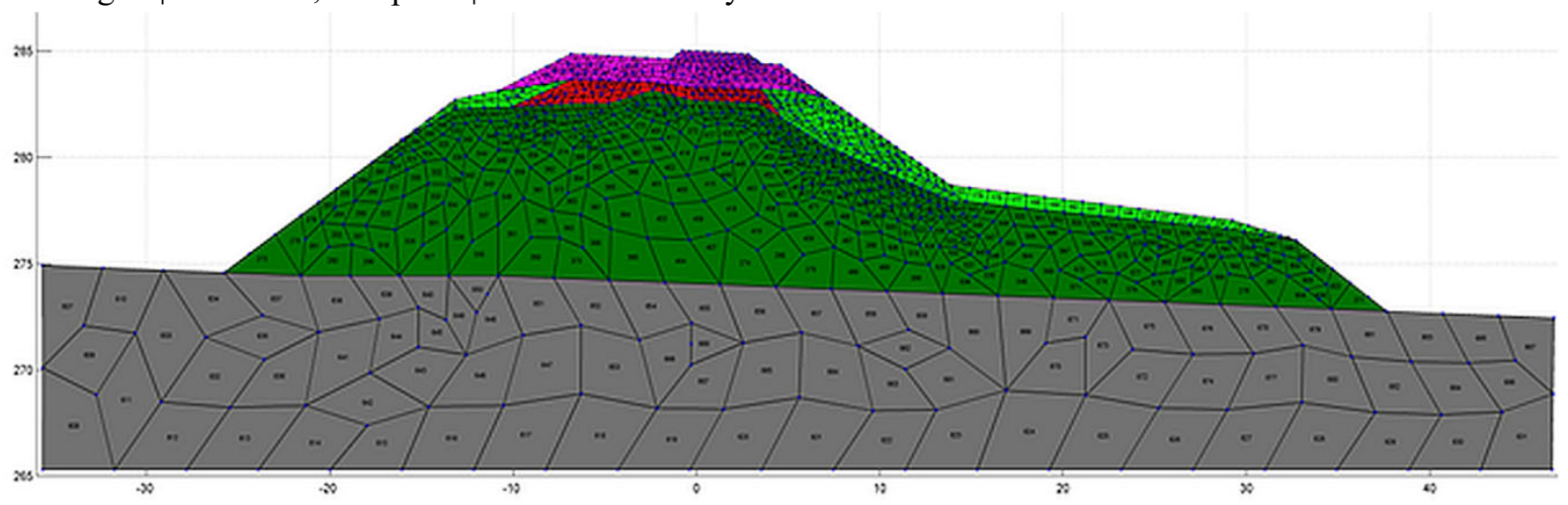

Fig. 3. Scheme of finite elements model in transverse section of the embankment

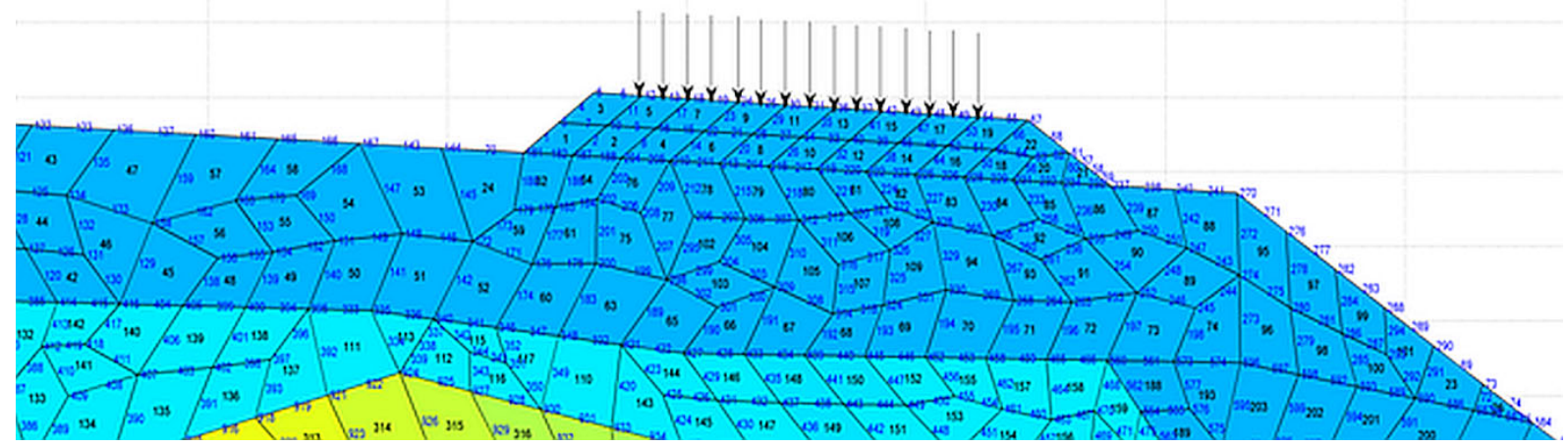

Fig. 4. Scheme of external dynamic loads distribution from the sleeper to the nodes of the ballast layer

To simulate the passage of dynamic oscillations in the transverse section of the embankment, a time interval of $0-0.2$ seconds is chosen that corresponds to several periods of oscillation at each point of the cross section of the embankment. It is not expedient to perform calculations over a longer period of time, since the greatest interest in the study is the maximum values of amplitudes of oscillations, and after the first periods of oscillation, their attenuation occurs. Fig. 5 shows variations of dynamic displacement of the points of the subgrade at a different depth below the middle part of the sleeper in the interval of 0.2 seconds after the start of dynamic loads application. The calculation is based on the developed software.

Fig. 6 shows distribution of oscillations amplitudes of soil points dynamic movement in the cross section of the subgrade. The graph shows that the largest amplitudes of oscillations reach $110 \mathrm{mkm}$ and are at the point of dynamic loads application from the sleeper. At the same time amplitudes of oscillations quickly fade in depth starting from the surface of the subgrade and along the slopes. 


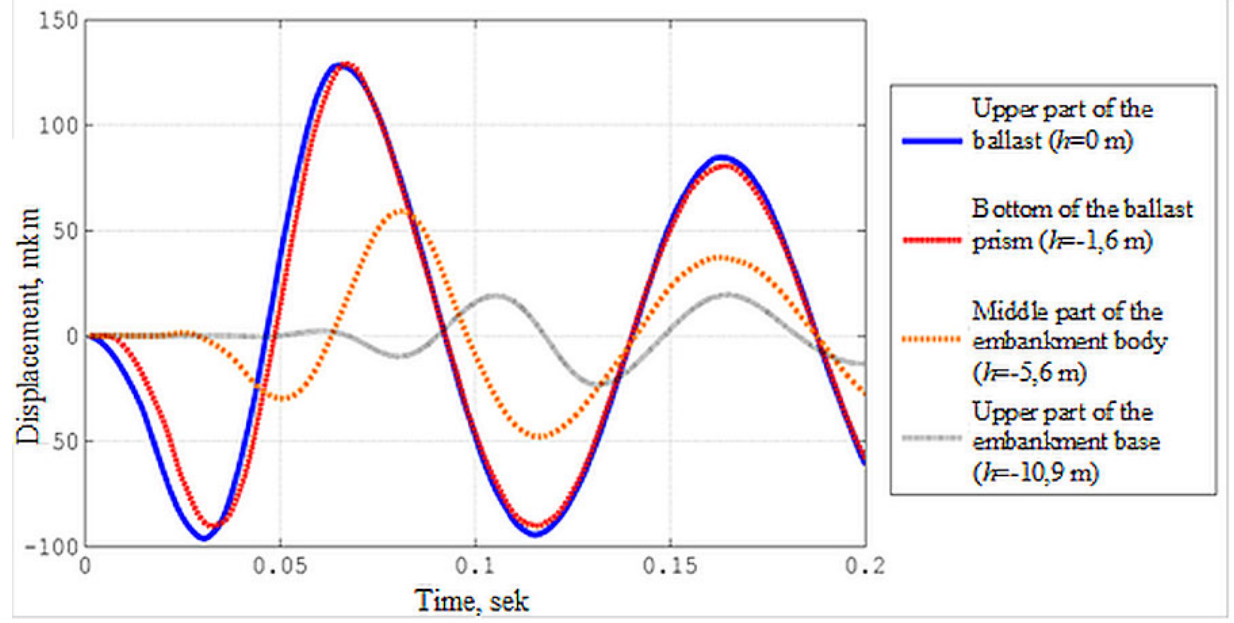

Fig. 5. Oscillation of subgrade points under the sleeper (ballast - subgrade - base of the embankment)

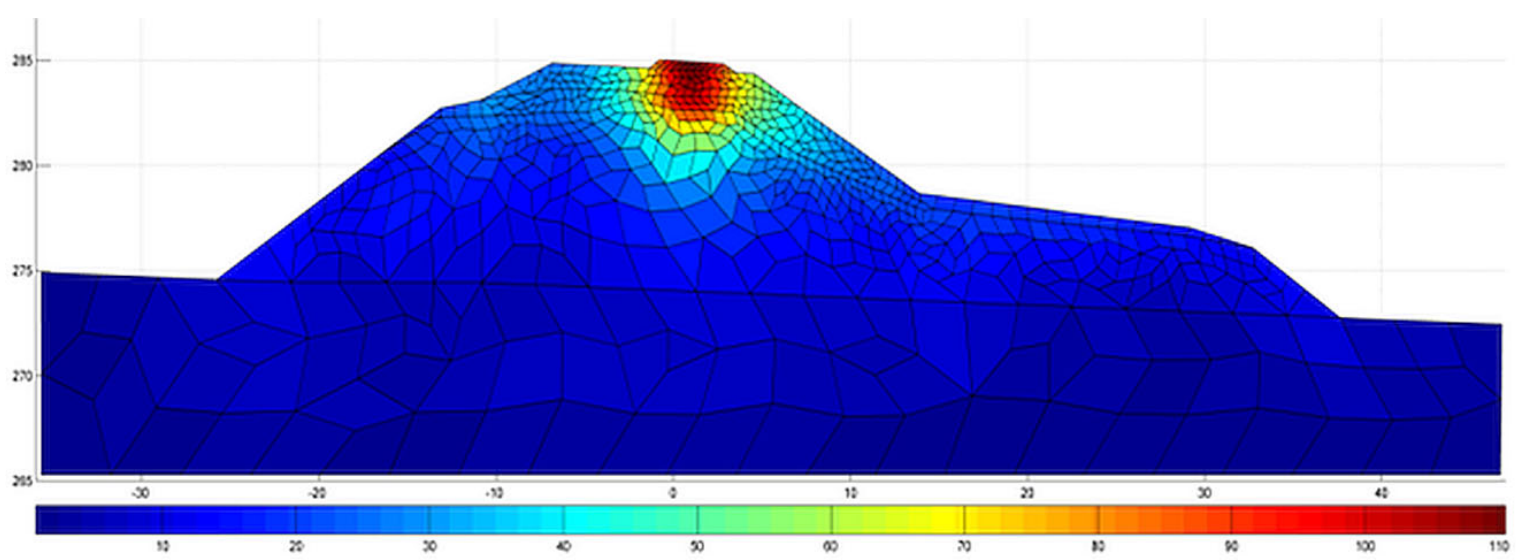

Fig. 6. Distribution of oscillations amplitude of dynamic displacements in the cross section of the embankment

\section{Method of elastic and plastic deformations of the subgrade body, taking into account the impact of vibro-loading and moisture on mechanical properties of soils}

\section{Calculation of soil strength characteristics of the subgrade, taking into account vibro-dynamic impact of rolling stock.}

Under the action of vibrational dynamic loads of rolling stock, there is a significant reduction in the value of subgrade soils bearing capacity. To evaluate the impact of vibrational dynamic action of rolling stock on the characteristics of soil strength, the technique developed by the scientists of PSURT Prokudin I.V., Kolos A.F., and others is used and approved by the Ministry of Railways of the Russian Federation for the assessment of the quality of the railway track base [20]. This technique is the basis of many modern studies of the subgrade stability [21, 22]. According to it, and in order to evaluate the effect of vibrational dynamic action on soil deformative and strength characteristics, the indices of relative reduction of specific adhesion and the angle of internal friction of the soil are used, which are determined in parts or percentages by the formulas:

$$
\begin{gathered}
K_{\mathrm{c}}=\frac{C_{s t}-C_{d y n}^{\min }}{C_{s t}} K_{\varphi}=\frac{\varphi_{s t}-\varphi_{d y n}^{\min }}{\varphi_{s t}}, \\
K_{\mathrm{c}}^{\prime}=\frac{C_{d y n}^{\min }}{C_{s t}} K_{\varphi}^{\prime}=\frac{\varphi_{d y n}^{\min }}{\varphi_{s t}},
\end{gathered}
$$

where $C_{s t}, \varphi_{s t}$ - specific adhesion and angle of internal friction of the soil, which are determined under the action of static loads; $C_{d y n}^{\min }, \varphi_{d y n}^{\min }-$ specific adhesion and angle of internal friction of the soil, which are determined under the action of maximum vibro-dynamic loads.

The most important factors affecting soils strength are soil moisture, its density, the magnitude of stresses pulsation or the amplitude of oscillations, soil deformation to vibro-dynamic effect and stressed state of the subgrade soil. Patterns of clutch change, angle of internal friction and deformation module with increasing vibro-dynamic impact are the main factors that determine the state and ability of soils to resist external loads.

Taking into account the proportional dependence of oscillations amplitudes on voltage pulsation, the law of strength change and deformation characteristics, the magnitude of soils oscillation amplitudes is described by the following formulas: 


$$
\begin{gathered}
C_{d y n}=C_{s t}\left[K_{\mathrm{c}}^{\prime}+K_{\mathrm{c}} \exp \left(-K\left(A-A^{\mathrm{H}}\right)\right)\right], \\
\left.\varphi_{d y n}=\varphi_{s t}\left[K_{\varphi}^{\prime}+K_{\varphi} \exp (-K A)\right)\right],
\end{gathered}
$$

where, $K_{\mathrm{c}}, K_{\mathrm{c}}^{\prime}, K_{\varphi}, K_{\varphi}^{\prime}$ are limiting values of relative decline of characteristics that determine soil deformation to vibro-dynamic loads; $K, K^{\prime}$ are coefficients of vibrational destruction and vibrational deformation; $A$ is the resulting amplitude of oscillation, at which the characteristics are determined; $A^{n}$ is an initial amplitude of oscillations, at which the reduction of characteristics does not exceed $3-5 \%$.

The study of soils of different composition and state with the largest volumetric mass obtained at standard soil consolidation with the humidity that is different from the optimum one, allowed to reveal the values of characteristics reduction, their correlation, coefficients of vibrational destruction and vibrational deformation, as well as initial amplitudes. The data about them are shown in Table 2.

To calculate the parameters $C_{d y n}$ and $\varphi_{d y n}$ for each soil of the subgrade and their distribution within its crosssection, the computation of the distribution of the resulting amplitude of oscillations $A$ in the subgrade is made using the developed model of dynamic oscillations of the subgrade in the transverse plane. Dynamic loads on the ballast layer from rolling stock are determined according to the TsP-0117 [19] being valid for the railways of Ukraine taking into account the main factors of vibrational loads.

Table 2. Indices of soil characteristics decline [14]

\begin{tabular}{|l|l|l|l|l|l|l|l|l|}
\hline \multirow{2}{*}{ Indices } & \multicolumn{8}{|l|}{ Came of the soil and its consistency } \\
\cline { 2 - 10 } & \multicolumn{2}{|c|}{ Clays with $I_{\mathrm{L}}$} & \multicolumn{2}{l|}{ Loam with $I_{\mathrm{L}}$} & \multicolumn{2}{l|}{ Sandy loam } \\
\hline & $0-$ & $0,15-$ & 0,45 & $0-$ & $0,15-$ & 0,45 & solid & plastic \\
& 0,15 & 0,45 & 0,45 & 0,15 & 0,45 & 0,4 & & \\
\hline$K_{\mathrm{c}}$ & 0,15 & 0,55 & 0,13 & 0,2 & 0,5 & 0,15 & 0,1 & 0,60 \\
\hline$K_{\mathrm{c}}^{\prime}$ & 0,85 & 0,45 & 0,87 & 0,80 & 0,50 & 0,85 & 0,90 & 0,4 \\
\hline$K_{\varphi}$ & 0,09 & 0,45 & 0,10 & 0,10 & 0,40 & 0,08 & 0,07 & 0,4 \\
\hline$K_{\varphi}^{\prime}$ & 0,81 & 0,55 & 0,90 & 0,90 & 0,60 & 0,92 & 0,93 & 0,60 \\
\hline$K^{\prime}$ & 0,005 & 0,01 & 0,015 & 0,006 & 0,011 & 0,02 & 0,006 & 0,025 \\
\hline$K$ & 0,01 & 0,012 & 0,018 & 0,008 & 0,012 & 0,015 & 0,007 & 0,02 \\
\hline$A^{\mathrm{H}}$ & 10 & 15 & 0 & 15 & 20 & 0 & 10 & 20 \\
\hline
\end{tabular}

Fig. 7 and Fig. 8 show the results of calculations of distribution parameters $C_{d y n}$ and $\varphi_{d y n}$ taking into account vibrational impact.

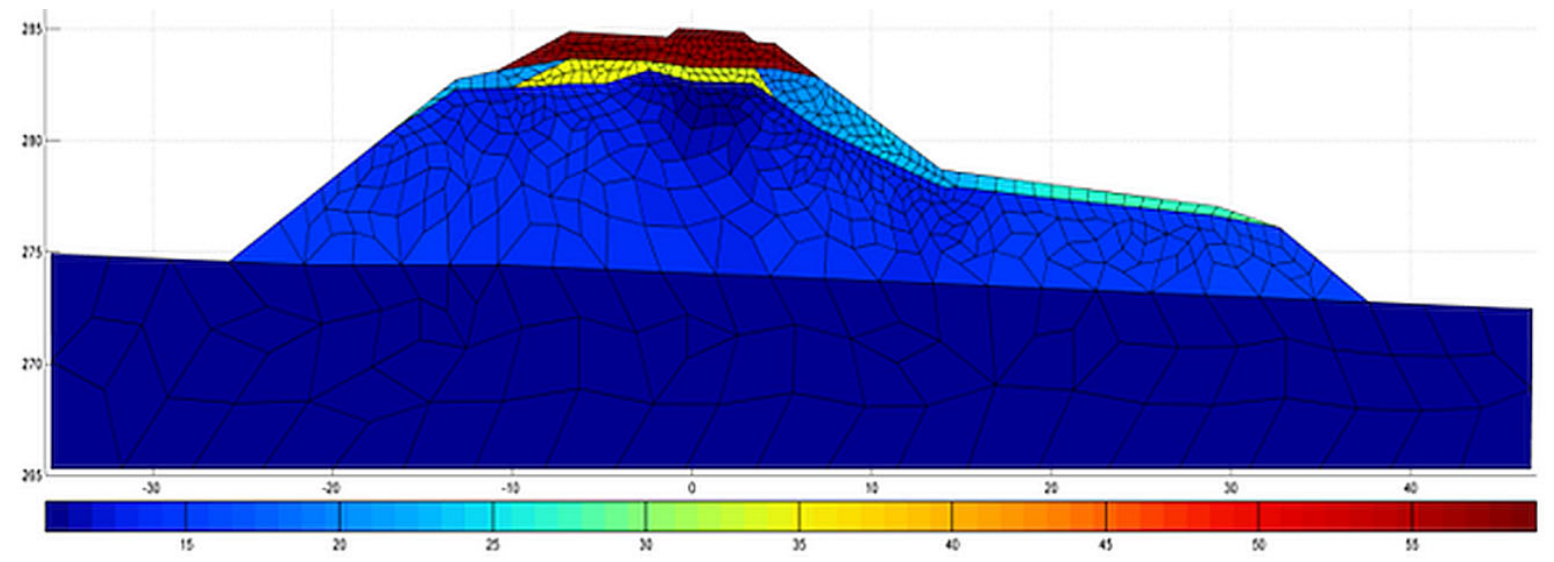

Fig. 7. Scheme of distribution of the angle of internal friction of the soil $\varphi_{d y n}$ in the cross section of the subgrade, taking into account vibrational impact

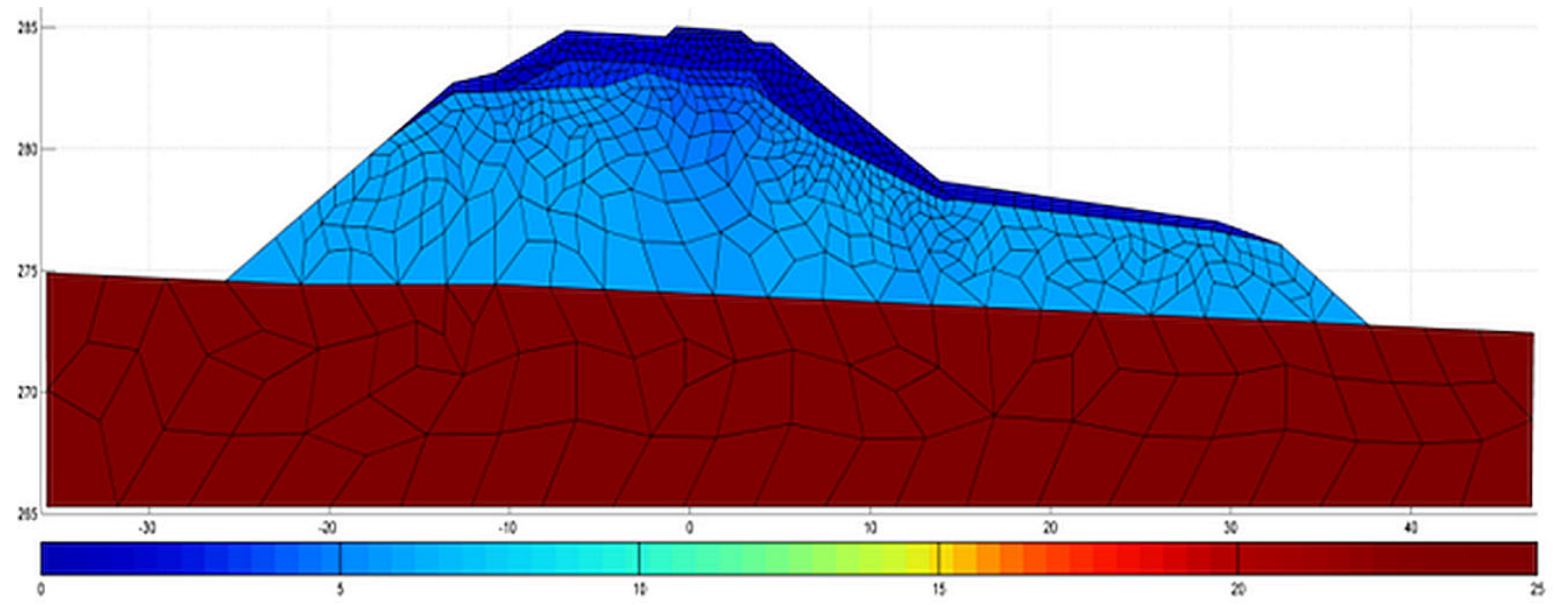

Fig. 8. Scheme of distribution of specific soil cohesion $\mathrm{C}_{d y n}$ in the cross section of the subgrade, taking into account vibrational impact 
Charts in Fig. 7 and Fig. 8 show that a significant vibrational dissociation occurs in the distribution of the angle of internal friction, namely in the body of the embankment made of loam and ballast plume, which are close to the zone of vibration loads application. Vibrational loads have also an impact on the reduction of specific adhesion in the loam of the body of the embankment.

\section{Example of calculation of the railway track stability under the impact of adverse operational, hydrometeorological conditions and its elements damage.}

\section{Calculations of plastic deformations of the embankment of the subgrade}

The displacement of the slope of the subgrade can be influenced by a number of factors in their mutual combination:

Factor 1. Low safety margin of the existing subgrade, due to the presence of inhomogeneous and weak soils in its composition (gravity loads, constant factor).

Factor 2. Dynamic loading of rolling stock, which depends on the type and speed of trains, running gear of rolling stock, geometrical state of the track, etc.

Factor 3. Reduced soils strength due to their humidification by short intense atmospheric precipitation.

Factor 4. Dismantling of a part of holding elements of the subgrade and the embankment during replacement of a pipe culvert by a repair crew.

To determine the degree of impact of these factors separately and in a mutual combination, it is necessary to make calculations of the coefficient of stability of the slope according to the developed model of deformation of the subgrade in all possible combinations, as shown in Table 3.

Thus, there are only 8 cases of calculating the stability of the subgrade: 1 . In the absence of loads of rolling stock, atmospheric precipitation and repair works; 2. Under the impact of rolling stock without atmospheric precipitation and repair works; 3 . Under the impact of atmospheric precipitation without trains traffic and repair works; 4. Under repair works performance without atmospheric precipitation and trains traffic; 5. Under the impact of rolling stock and atmospheric precipitation without repair works; 6 . Under the impact of rolling stock and repair works without atmospheric precipitation; 7. Under repair works performance without atmospheric precipitation and trains traffic; 8 . Under the impact of rolling stock, repair works and atmospheric precipitation.

Table 3. Possible cases of factors combination

\begin{tabular}{|l|c|c|c|c|}
\hline $\begin{array}{l}\text { Calculation } \\
\text { variants }\end{array}$ & $\begin{array}{c}\text { Factor } \\
1\end{array}$ & $\begin{array}{c}\text { Factor } \\
2\end{array}$ & $\begin{array}{c}\text { Factor } \\
3\end{array}$ & $\begin{array}{c}\text { Factor } \\
4\end{array}$ \\
\hline 1 & $\mathrm{x}$ & & & \\
\hline 2 & $\mathrm{x}$ & $\mathrm{x}$ & & \\
\hline 3 & $\mathrm{x}$ & & $\mathrm{x}$ & \\
\hline 4 & $\mathrm{x}$ & & & $\mathrm{x}$ \\
\hline 5 & $\mathrm{x}$ & $\mathrm{x}$ & $\mathrm{x}$ & \\
\hline 6 & $\mathrm{x}$ & $\mathrm{x}$ & & $\mathrm{x}$ \\
\hline 7 & $\mathrm{x}$ & & $\mathrm{x}$ & $\mathrm{x}$ \\
\hline 8 & $\mathrm{x}$ & $\mathrm{x}$ & $\mathrm{x}$ & $\mathrm{x}$ \\
\hline
\end{tabular}

It is known from the geological section of the subgrade that from the side, where the slope of the subgrade has occurred, there is a ballast plume (Soil 4) with a thickness up to $1 \mathrm{~m}$ (Fig. 9). Proceeding from this, we can assume that there was a significant moisture of upper drainage soils of the embankment, namely Soils 35. It is known from a number of sources that soil moisture significantly reduces their strength characteristics [23, 24, 25], namely, sliding characteristics: specific adhesion $C_{s t}$ and the angle of internal friction $\varphi_{s t}\left(\operatorname{tg}\left(\varphi_{s t}\right)=f_{s t}\right)$ under condition of moisture decrease:

$$
\begin{aligned}
& C_{v}=(0,5 \ldots 0,6) C_{s t} \\
& f_{v}=(0,75 \ldots 0,85) f_{s t},
\end{aligned}
$$

We accept extreme lower limits for lowering landslide characteristics of soils: 0.5 for specific clutch and 0.75 for the angle of internal friction, respectively.

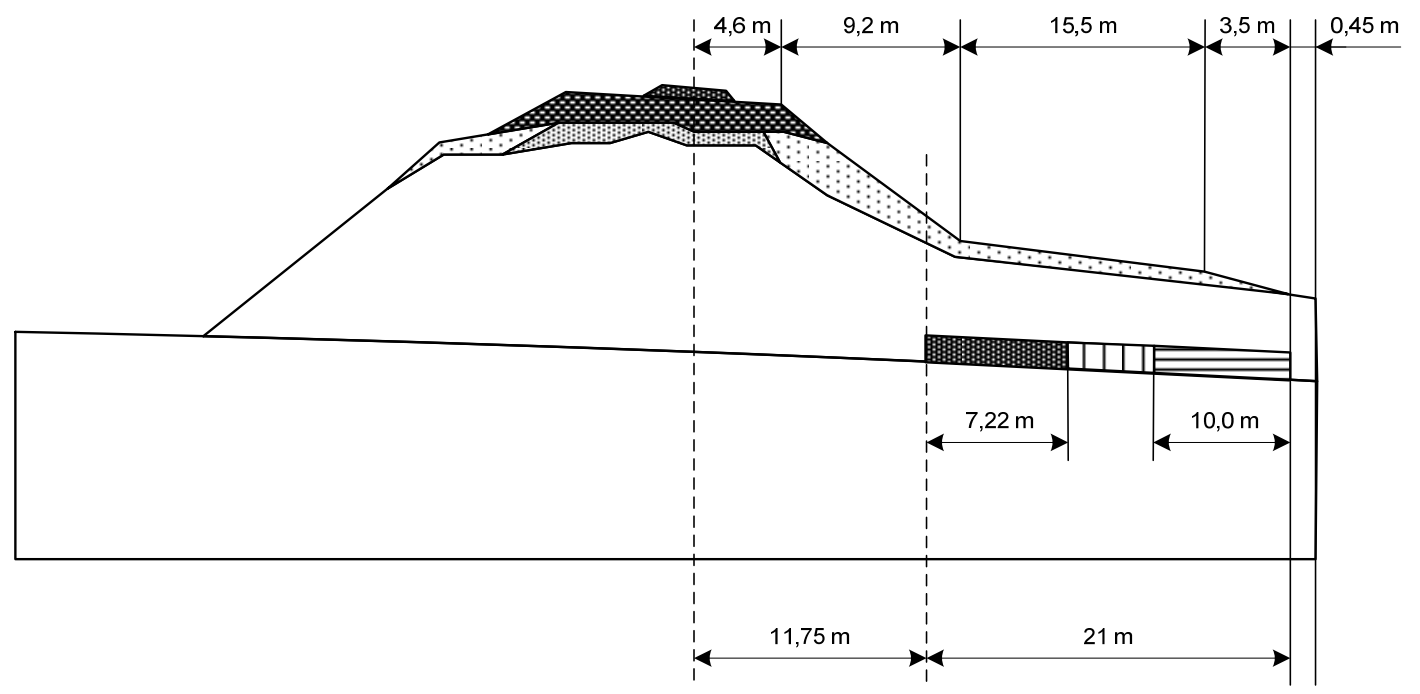

Fig. 9. Cross-section of the embankment and the scheme of pipe culvert dismantling 


\section{Calculation of stability when performing repair works and under the impact of adverse factors}

When performing subgrade dismantling for the distance of $11.75 \mathrm{~m}$ from the axis of the unpaired track without atmospheric precipitation, without trains traffic and the coefficient of parameters change of sliding strength less than 1.18 is the attenuation of intensity of average subsidence (red line in Fig. 10) to $2 \mathrm{~mm}$. At higher values of the coefficient there is a gradual increase in subsidence rate, that is, the destruction of the subgrade, in this case, will be gradual (Fig. 11, 12). Coefficient of stability of the embankment $\mathrm{k}_{\mathrm{y}}=1.18$ is adopted.

The results of determining stability coefficients for various combinations of factors impact are summarized in Comparative Table 4.

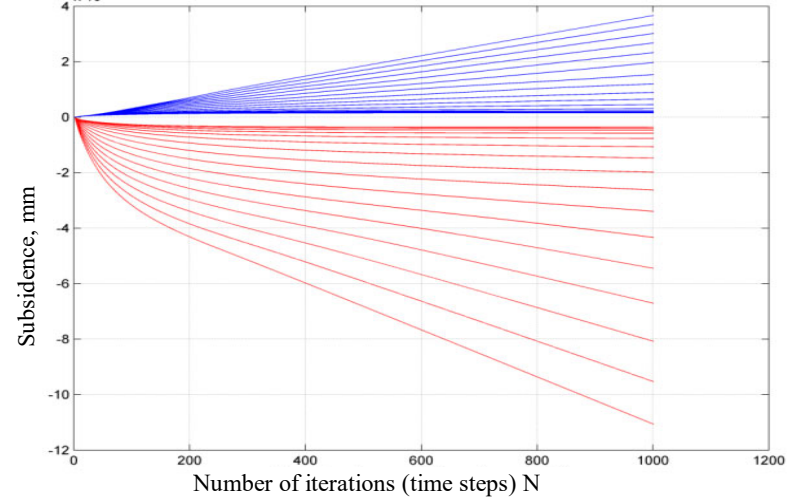

Fig. 10. Average and uneven subsidence of points of a ballast prism surface depending on the step of "pseudo-time" under the increase of the coefficient of parameters change of sliding strength of soils

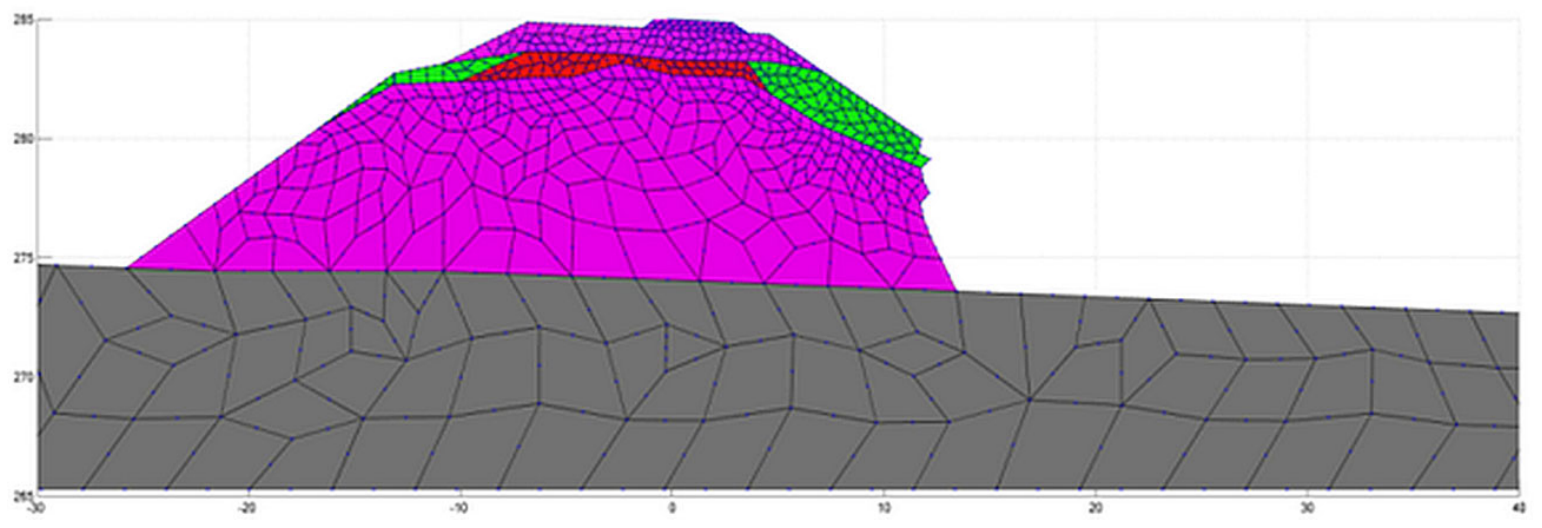

Fig. 11. Transverse profile of the embankment after dismantling of the subgrade to destruction

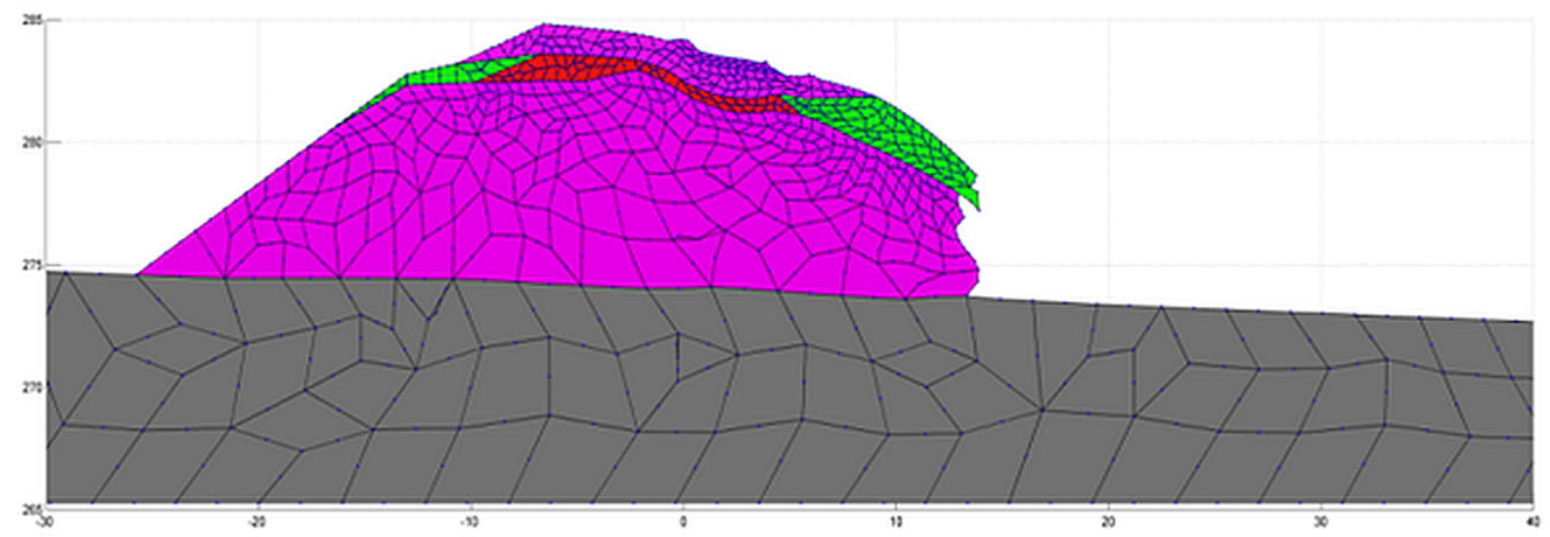

Fig. 12. Plastic deformations of the transverse profile of the embankment at the moment of displacement beginning (deformation increased by 500 times)

Table 4. Possible cases of influence of factors combination and safety margin coefficients

\begin{tabular}{|l|c|c|c|c|c|}
\hline Calc. variants & Factor 1 & Factor 2 & Factor 3 & Factor 4 & $\mathrm{k}_{\mathrm{y}}$ \\
\hline 1 & $\mathrm{x}$ & & & & 2,1 \\
\hline 2 & $\mathrm{x}$ & $\mathrm{x}$ & & & 1,45 \\
\hline 3 & $\mathrm{x}$ & & $\mathrm{x}$ & & 2,05 \\
\hline 4 & $\mathrm{x}$ & & & $\mathrm{x}$ & 1,18 \\
\hline 5 & $\mathrm{x}$ & $\mathrm{x}$ & $\mathrm{x}$ & & 1,36 \\
\hline 6 & $\mathrm{x}$ & $\mathrm{x}$ & & $\mathrm{x}$ & 0,98 \\
\hline 7 & $\mathrm{x}$ & & $\mathrm{x}$ & $\mathrm{x}$ & 1,1 \\
\hline 8 & $\mathrm{x}$ & $\mathrm{x}$ & $\mathrm{x}$ & $\mathrm{x}$ & 0,92 \\
\hline
\end{tabular}

Analysis of the influence of repair works and precipitation on the strength of the subgrade.

The results of the study show that the subgrade of the embankment under the impact of rolling stock at the speed of $55 \mathrm{~km} / \mathrm{h}$ and without intensive moistening, has a safety margin against rapid loss of stability of 1.45 .

When dampening the upper drainage layers of the subgrade with storm atmospheric waters, the safety margin against rapid loss of resistance decreases to 1.36 , 
although, at the same time, there are slow deformations that do not threaten safety traffic. When disassembling the subgrade at a distance of $11.75 \mathrm{~m}$ from the axis of the track and absence of a heavy shower, the subgrade is in the near-crucial state without a stock of stability.

Calculations show that with significant moisture and disassembled subgrade to a distance of $11.75 \mathrm{~m}$ from the axis of the track, the embankment is in the stable state with a stock of stability of 1.1, but in case of atmospheric precipitation, the embankment has a coefficient of stability equal to 0.98 , that is, it is in an unstable state.

Thus, considering the influence of each of the factors separately, it can be seen that the effect of factor 4 (disassembly of the subgrade) is the largest and reduces the resistance by $44 \%$, factor 2 (rolling stock) reduces the resistance by $31 \%$, and factor 3 (storm atmospheric precipitation) has the least impact - about $3 \%$.

Considering the effect of factor 3 (storm atmospheric precipitation) and factor 4 (disassembly of the subgrade) and excluding the impact of factor 2 (rolling stock), it can be stated that storm atmospheric precipitation caused $6 \%$ decrease in stability, and disassembly of the subgrades caused $32 \%$ of decrease in the stability of the subgrade.

\section{CONCLUSIONS}

The vibrational loading impacts the reduction of specific adhesion and the internal friction angle of the body of the embankment of the railway track.

When dampening the upper drainage layers of the subgrade with storm atmospheric precipitation, the safety margin against rapid loss of resistance decreases to 1.36 , which does not endanger safety traffic.

Calculations show that in the disassembled subgrade to a distance of $11.75 \mathrm{~m}$ from the axis of the track the embankment is in the stable state with a stability reserve of 1.1 , but in case of atmospheric precipitation the embankment has the coefficient of stability equal to 0.98 , that is, it is in an unstable state.

The analysis of the influence of each of the factors separately, shows that the influence of subgrade dismantling is the largest, and it reduces the resistance by $44 \%$, the impact of rolling stock reduces the stability of the subgrade by $31 \%$, and the impact of atmospheric precipitation is about $3 \%$. Considering the effect of storm atmospheric precipitation and dismantling of the subgrade, and excluding the impact of rolling stock, it can be stated that the storm atmospheric precipitation caused $6 \%$ decrease in the stability of the subgrade, and the dismantling of subgrades caused $32 \%$ resistance decrease.

\section{REFERENCES}

1. Briggs, KM, Loveridge, FA and Glendinning, S Failures in transport infrastructure embankments. Engineering Geology, 219. pp. 107-117 (2017)

2. Ižvolt, L., Šestáková, J., Šmalo, M. Tendencies in the development of operational quality of ballasted and ballastless track superstructure and transition areas. IOP Conference Series: Materials Science and Engineering, 236(1), 012038 (2017)

3. Zhang, Q., Gao, Y., Zhang, H.-X., Xu, F., Li, F. Risk identification, assessment and monitoring design of high cutting loess slope in heavy haul railway. Structural Monitoring and Maintenance, 5(1), pp. 67-78 (2018)

4. Qian Zhang, Jing Wang, Wenyu Wang, Songsong Bai \& Peng Lin, Study on slope stability due to the influence of excavation of the high-speed rail tunnel, Geomatics, Natural Hazards and Risk, 10:1, 11931208 (2019)

5. M. P. Sysyn Vplyv dsbratciinoho navantagennia ruchomoho skladu na robotu hruntiv zemlianoho polotna Zaliznytchnyi transport Ukrainy. № 2. P.P. 51-54 (2012) [in Ukrainian]

6. Libor Ižvolt, Peter Dobeš, Alžbeta Pultznerová, Monitoring of Moisture Changes in The Construction Layers of the Railway Substructure Body and Its Subgrade, Procedia Engineering 161 1049 - 1056 (2016)

7. Sysyn Mykola, Nabochenko Olga, Kovalchuk, Vitalii, Gerber Ulf Evaluation of Railway Ballast Layer Consolidation After Maintenance Works ACTA POLYTECHNICA, 59(1), Pages: 77-87 (2019), DOI: 10.14311/AP.2019.59.0077. Accession Number: WOS:000462321600009.

8. Sz. Fischer, f. Horvát, Investigations of the reinforcement and stabilisation effect of geogrid layers under railway ballast, Slovak journal of civil engineering, Vol. XIX, No. 3, 22 - 30 (2011) DOI: 10.2478/v10189-011-0015-y

9. Plasek, Otto; Hruzikova, Miroslava; Svoboda, Richard; INFLUENCE OF UNDER SLEEPER PADS ON TRACK QUALITY, AKUSTIKA, 23:28-33, 2015

10. Szabolcs Fischer, Breakage Test of Railway Ballast Materials with New Laboratory Method, Periodica Polytechnica, Civil Engineering, 61 (4), pp. 794802, 2017, https://doi.org/10.3311/PPci.8549

11. Sysyn Mykola, Gerber Ulf, Nabochenko Olga, Gruen Dmitri, Kluge Franziska Prediction of Rail Contact Fatigue on Crossings Using Image Processing and Machine Learning URBAN RAIL TRANSIT, Volume: 5, Issue2, Pages: 123-132 (2019) DOI: $10.1007 / \mathrm{s} 40864-019-0105-0$. Accession Number: WOS:000471653400004.

12. Sysyn Mykola, Gerber Ulf, Gruen Dimitri, Nabochenko Olga, Kovalchuk, Vitalii Modelling and vehicle based measurements of ballast settlements under the common crossing EUROPEAN TRANSPORT-TRASPORTI EUROPEI, Issue: 71, Article Number: 5, (2019) Accession Number: WOS:000462060400005.

13. Danilenko E. I., Rybkin V. V. Pravyla rozrakhunkiv zaliznychnoi kolii na micnist $i$ stiikist (CP/0117). Kyiv: Transport Ukrainy - 168 p. (2006) [in Ukrainian] 
14. Shachuniants G. M. Ustroistvo zheleznodorozhnogo puti Moskva: Transzheldorizdat, (1944) [in Russian]

15. Kohan A. Ya. Dinamika puti i eho vzaimodeistvie $s$ podvizhnym sostavom Moskva: Transport,. - $326 \mathrm{p}$. (1997) [in Russian]

16. Chernyshev M. A. Prakticheskie metody rascheta puti. / Чернышев М.A. - М.: Транспорт, 1967. - 236 с. [in Russian]

17. Prokudin I. V. Hrachev I. A., Kolos A. F. Organizatsiia pereustroistva zheleznych doroh pod skorostnoe dvizhenie poezdov, Moskva: Marshrut,. 716 p. (2005) [in Russian]

18. Osnovy ta fundamenty sporud. Osnovni polozhennia proektuvannia. DBN V.2.1-10-2009. Kyiv: Minrehionbud Ukrainy. - 104 p. 2009 [in Ukrainian]

19. Danilenko E. I. Zaliznychna koliia. ulashtuvannia, proektuvannia $i$ rozrakhunki, vzaiemodiia $z$ rukhomym skladom. Kyiv, Inpres,. - Tom 2. 456 p. (2010) [in Ukrainian]

20. Rekomendacii po intensivnoi tekhnolohii i monitoring stroitelstva zemlianykh sooryzhenii na slabykh osnovaniiakh Moskva: «Timr»,. 96 p. 2005 [in Russian]
21. Simmer K. Grundbau: Bodenmechanik und erdstatische Berecnungen Stuttgart: Teubner B.G. $\mathrm{GmbH},-430$ p. (2009)

22. Lichtberger B. Handbuch Gleis: Unterbau, Oberbau, Instandhaltung, Wirtschaftlichkeit. Hamburg: Tetzlaff Verlag, 318 p. 2003

23. Vorlesungensammlung von Lehrstuhl für Grundbau, Bodenmechanik, Felsmechanik und Tunnelbau. München: TUM Zentrum Geotechnik, pp.1-28 (2011)

24. Kornev D. A. Ocenka naptiazhennodeformirovannoho sostoianiia zheleznodorozhnykh nasypei $s$ primeneniem obiemnykh geomodelei Avtoreferat dissertacii na soiskaniie uchenoi stepeni kandidata tekhnicheskich nauk spec. 05.23.11 Proektirovaniie i ctroitelstvo doroh, metropolitenov, aerodromov, mostov i transportnykh tonnelei. SHUPS, Novosibirsk, 28 p. (2009) [in Russian]

25. Daniliants E. S. Prohnoz naprizhennodeformirovannoho sostoianiia zheleznodorozhnoho zemlianoho polotna s utchetom vibrodinamicheskoho vozdeistviia poezdov Avtoreferat dissertacii na soiskaniie uchenoi stepeni kandidata tekhnicheskich nauk spec. 05.22.06 Zheleznodorozhnyi put, izyskaniie i proektirovanie zheleznykh doroh. DVHUPS, Khabarovsk, 24 p. (2009) [in Russian] 